\title{
THE USE OF ICT IN AUTHENTIC ASSESSMENT OF THE STUDENTS' PRODUCTIVE SKILLS
}

\author{
Wardah Zahra \\ English Education Department, Faculty of Teaching Training and Education, Sriwijaya University, Indonesia \\ Email:wzahraa@gmail.com
}

Rita Inderawati (Corresponding Author)

English Education Department, Faculty of Teaching Training and Education, Sriwijaya University, Indonesia Email: rita_inderawati@fkip.unsri.ac.id

Ismail Petrus

English Education Department, Faculty of Teaching Training and Education, Sriwijaya University, Indonesia Email: ismailpetrus@yahoo.com

\begin{abstract}
APA Citation: Zahra, W., Inderawati, R., \& Petrus, I. (2019). The use of ICT in authentic assessment of the students' productive skills. English Review: Journal of English Education, 8(1), 81-90. doi: 10.25134/erjee.v8i1.2110.
\end{abstract}

\begin{abstract}
Making use of ICT and applying authentic assessment in the teaching and learning activities represent an obligatory from Indonesian Ministry of Education and Culture. This study aimed at finding out types of ICT used in the authentic assessment of the productive skills, describing the implementation of ICT in the authentic assessment of the productive skills, explaining the possible problems faced by the English teachers in the implementation, and explaining the solution used by the teachers to solve the problems. This study was a descriptive study with qualitative approach. The data were collected through interview, observation, and documentation to three English teachers, a curriculum coordinator, a facility and infrastructure administrator, and three students, were validated through methodological triangulations and were analyzed using Miles and Huberman's analysis model (1994), namely data reduction, data display and conclusion, and verification. The results discovered that there were three types of ICT in the authentic assessment of the productive skills, the teachers had different methods in implementing the three types of ICT tools based on the types of authentic assessment concerning aspects of productive skills, they encountered three main problems in the implementation, and they were educated and motivated to have their solutions to overcome the difficulties.
\end{abstract}

Keywords: ICT; authentic assessment; ICT-based authentic assessment; speaking skill; writing skill.

\section{INTRODUCTION}

An unprecedented revolution in information and communication technologies (ICT) has been changing the standard and nature of the English language by imposing new practices that have been influencing how the students are evaluated in the current years. For the students growing up in a culture of technology integration, ICT provides relevant new learning and assessment chances that are in related to their real-world activities. Similarly, Jonassen, Howland, and Marra (2009) point out that the use of technology to support assessment is not only done by converting traditional forms of assessment into a digital format, but it can also be used to assess higher-order learning outcomes based on the realbased situation as students have chances to demonstrate what they learn. Mueller (2014) agrees that authentic assessment as a form of assessment which requires the students to achieve real-world tasks as a purposeful implication of knowledge and skills.

Categorically, Luo and Lei (2012) confirm that there are four different common types of ICT in educational purposes, those are, (1) educational networking: an educationally focused network which is accessed by online (Ning), (2) web-based learning: an internet-based instructional delivery tool or online application or services allowing those who access the platform to have interactively collaboration in searching, accepting, organizing, and delivering educational content (wiki, social bookmarking, blog, and podcast), (3) mobile learning: means of technologies conducted by portable devices aiding in educational activities (smartphones and laptop), and (4) classroom equipment: any facilitation in the form of devices to support the interaction between the teachers and the students in classroom (projectors and speakers). Thus, the 
applicable achievement of the language learning activities would help the students to bestow their knowledge into the real-life situation.

Productive skills-speaking and writing skills have relation to authentic assessment since they may occur the opportunities to develop real-life activities relevantly. According to Harmer (2015), productive skills are the skills in a language produced by the students. In other words, the students need to articulate and write words to generate language. Aspects of speaking include fluency - the involvement of the speakers to be able to keep maintaining the utterance spontaneously and accuracy-vocabulary, grammar, and pronunciation. In writing, the aspects are handwriting, correct spelling, punctuation, and layout. (Harmer 2015; Nunan 2003). Specifically, authentic assessment involving ICT in the speaking practices can be in the form of oral practice or presentation using computers, movie-based description, digital story or text retelling, radio broadcasts, voice or video conferences, web-based video clips and digital oral directed report. In another productive skill, writing skill practices, the assessment is classified into computer-based writing practices, a website learning and online publication, and written presentation. (Thanyalak, 2012; Zhang \& Han, 2012).

Indonesia, one of the non-English-speaking countries, emphasizes on productive skills measured by authentic assessment together with the use of ICT in its latest curriculum. According to the regulation of the Ministry of Education and Culture Numbers 27 and 22 Years 2017 and 2016 about graduate competency and process standards, teachers of English should specifically focus on productive skills of English and emphasize on the implementation of ICT to improve efficiency and effectiveness in teaching and learning activities. In reality, there are still several constraints in educational practice. The most common problems in relation to the use of ICT in assessing the students of non-Englishspeaking countries are the teachers are lack of sufficient skills and knowledge about ICT, limited to ICT facilities, accessibilities, network connection, time, and training. (UNESCO, 2011).

In terms of ICT development, Indonesia is ranked 111 out of 176 countries worldwide (International Telecommunication Union, 2017). Badan Akreditasi Nasional (2018) shows that the standard of educators and education personnel are grouped in the three lowest standards. Identically, Zaim (2013) in his study found out that English teachers faced difficulties in constructing appropriate assessment instruments to evaluate oral and written language skills. $\mathrm{He}$ found that teachers were not confident in describing the theory of authentic assessment as they merely do not understand the authentic assessment. Trisanti (2014) also discovered that some teachers did not have enough basic theory of authentic assessment. The application of scoring rubrics was unclear for them. Thus, the low level of English proficiency probably comes from lack ability of the teachers in administering and evaluating the materials that would be responsible to low scores of the students' productive skills.

In line with the rationales, the writer decided to have SMA LIGM as the further observed school in discovering types of ICT in authentic assessment of productive skills in the academic year 2019/2020, describing the implementation the assessment to measure the students' English productive skills, elaborating the difficulties in implementing it and the solution used by the teachers to overcome those difficulties. Based on the vision and mission of the school, the implementation of authentic assessment together with ICT is highlighted. Likewise, the curriculum development of the school standardizes that teaching and learning activities must be based on scientific approach and evaluated by conducting authentic assessment involving learning, motivation, and attitudes. Additionally, the school intends to consider ICT in every aspect of teaching and learning activities aiming to create conducive learning situation. The utilization of ICT is expected to result in the students to be globally qualified in the workplaces.

\section{METHOD}

This study was a descriptive qualitative study concerning the use of ICT in the processes of authentic assessment. Fraenkel and Wallen (2012) state that a descriptive method is a method used to explain, analyze and classify something through various techniques, survey, interview, questionnaires, observation, and text. The qualitative approach resulted organized and authentic descriptions of the investigation of relationships, activities, situations and materials in descriptive phenomena such as words, sentences, and utterances.

This study involved three English teachers at SMA LIGM, a curriculum coordinator, a facility and infrastructure administrator, one student of science grade XI taught by teacher 1 (student A), 
one student of social grade XI taught by teacher 2 (student B), and one student of grade $\mathrm{X}$ taught by teacher 3 (student $\mathrm{C}$ ). The students that were chosen were the representatives who got actively involved in the classroom activities of the teachers. In the data collection, the teachers of English, were interviewed (semi-structured) and observed. Similarly, the curriculum coordinator, the facility and infrastructure administrator, and the students were also interviewed with the unstructured questions. The last, some documents related to the activities during the investigation were reviewed.

To validate the data, a methodological triangulation technique was used. Cohen, Manion, and Morrison (2011) determine this technique as the use of more than one instrument in collecting data. It may involve interviews, questionnaires, observations, and documents. After the data were obtained, they were analyzed by using three steps of Miles and Huberman's (1994) analysis model, which include; data reduction: focusing on the specified objectives of this study to make a detailed interpretation; data display and conclusion: displaying the analyzed data covering credible data in text and or tables to confirm the conclusion; and verification: examining through reference to the writer existing field notes and further data collection.

\section{RESULTS AND DISCUSSION}

The results of interviews, classroom observation, and documentation were analyzed into four main objectives to draw conclusions.

Types of ICT used in authentic assessment of the students' productive skills

\section{Mobile learning}

In the productive skills, all the three teachers operated mobile learning-laptop and smartphones and involved the students in the classroom assessment as the subject of the assessment. In the interview, teachers 1 and 3 frequently benefited smartphones and laptops to document and ask the students to do assignment in the speaking and writing skills assessment activities. Teacher 3 specifically said that she utilized some functions in students' smartphones such as social media like in Whats-App group and email to conduct the assessment in writing skill.

Additionally, although teacher 2 did not mention about the implementation of the smartphones as the media in the assessment activities during the interview, the observation found out that she utilized the smartphones in assessing speaking skill assessment. She recorded the students' performance through her smartphone and she shared the files to the students. Later, the students had peer assessment about the recordings. Moreover, teacher 2 involved the students to get in charge of designing both speaking and writing materials in the form of PowerPoint through laptops to be authentically assessed by the teacher 2. However, there was only one lesson plan (about caption text) stated that mobile learning (smartphones) as one of the learning media. It could probably because the teachers were not aware about the detailed lesson plans.

Throughout the authentic assessment activities enabled the teachers to design innovative creation of certain tasks on the basis of the students' reallife activities, Sharples et al. (2014) state that mobile learning allows the teachers to have innovative practices and social learning environment. Therefore, it can be said that by applying mobile learning as devices in measuring the students' productive skills through authentic assessment, the teachers creatively varied their kinds of means of authentic assessment focusing on the students' outcomes.

\section{Classroom equipment}

Since classroom equipment refers to any supporting devices in the classroom used by both the teachers and the students to construct interaction between them, all the findings showed that the three teachers run the provided classroom equipment in their assessment activities for the productive skills. In most assessment activities, the teachers frequently applied classroom equipment that was available in every classroom. The teachers engaged the students into both speaking and writing materials and stimulate them to demonstrate the materials that then would be assessed by the teachers. Identically, all of the teachers also listed the utilization of projectors in their lesson plans as one of the supporting tools in the classroom activities.

Likewise, according to the facility and infrastructure administrator, the projector in each classroom was in good quality as the projector was completed by its supporting equipment. She also mentioned about any other equipment that can be used by both the teachers and the students in the assessment activities such as the smart board and the language laboratory that could be used in turns. In relation to this, American Library Association (1998) states that the practical use of available technologies around the students motivate the students to learn faster, 
become problem-solvers and more self-regulated. Through the availability of the technologies around the students discovered in the findings, therefore, the students would certainly get positive contribution to their achievement.

\section{Web-based learning}

In authentic assessment for writing skill, the three teachers integrated the materials through internetbased instructional delivery tool or internet services. As concerns to the results of the teachers' interview, the teachers mainly focused on the internet-based materials in their authentic assessment activities which purposely involved the students in the activities. Teacher 1 applied the internet to stimulate the students to do some practices regarding their writing tasks. Besides, both teachers 2 and 3 accounted for the sources of their writing skill assessment from the internet. Particularly, teacher 2 asked the students to browse the materials by themselves through the internet such as blog and wiki and designed the sources into some PowerPoint files to be projected that were authentically assessed by the teacher.

Similarly, the findings of the observation resulted that all the teachers browsed some sites on the internet to look for materials to the students. The teachers used internet-based materials browsed from blogs and wiki. Likewise, the teachers also asked the students to browse additional information about the materials. After searching the materials, both the teachers and the students had brief discussions and assessment activities. In the lesson plans, the sources of websites as sources of learning were listed.

By means of this tool and the teachers' method, the students became more independent—not waiting the materials only from the teachers and they would have critical minds and this made the teachers focus on what the students were doing. It is in correlation with Wasim et al. (2014) has discovered in their study. They said that web-based learning helps the teachers to easily control the students to be more independent in learning. Furthermore, it also connects with the regulation in 2013 curriculum. According to Ministry of Education and Culture Number 27 the Year 2016 about graduate competence standard, it says that active learning should be centered to the students.
The implementation of ICT in the authentic assessment of productive skills of SMA LIGM students

\section{The implementation of mobile learning}

According to the interview and observation, smartphones were applied by both teachers 1 and 2 in the same way. These two teachers asked the students to record their performances of the authentic real-based material by means of the students' smartphones into videos. They engaged the students to get involved in teaching and learning activities as advised by Sharples et al. (2014) - they said that mobile learning helps the students to be more active. Specifically, the teachers recorded the students' performance through her smartphone and they shared the files to the students. In the assessment activities, the teachers measured the students' speaking skill based on the criteria or rubrics they have prepared. The benefits of mobile learning applied by both the teachers and the students certainly facilitated them in having comprehendible materials which were accessible and manageable.

In the writing skill, teacher 3 used the smartphone to facilitate her in sending the students' tasks. She asked the students to submit the tasks through e-mail and Whats-App group after the students finished demonstarating what teacher 3 asked during the assessment activities. The tasks mostly about the students' writing results of narrative text. Moreover, laptops were also chosen by the teachers to be one of ICT tools used by the students in typing the writing tasks about narrative and explanation text. However in the lesson plan, the only material stated mobile learning (smartphones) was about caption text. In the activities, the students were asked to upload and send the tasks through social media. Therefore, although the teachers properly applied mobile learning, they were still not able to detail their appropriate method and media in the activities to be put in the lesson plans.

\section{The implementation of classroom equipment}

According to the all findings of the instruments, the ICT that was available and utilized by the English teachers and the students at each classroom of SMA LIGM was multimedia projector. The materials mostly were conferenced through the projectors. After having the knowledge from what the teachers have taught, the students were asked to design their own PowerPoint that would be shared in front of the class through the projectors. During the presentation, the teachers assessed both the students' speaking and writing skill. The 
students' speaking skill was assessed while the students were having presentation and discussion by means of projectors. The writing skill was measured by the teachers through the PowerPoint that they had designed before the presentation. The materials chosen during the investigation were based on their real-life activities such as designing announcement and caption texts, describing certain objects around them to be critically analyzed in analytical exposition, and singing song lyrics.

Furthermore, as the teachers constructed the innovative environment of the classroom by having attractive materials or slides and engaging the students to make ones, the students seemed to easily understand the materials. It is in line with what Ozaslan and Maden (2013) have found in his study. They discovered that the interactive learning materials could help the students to learn better. Related to this finding, it happened in the school since all the teachers were not bounded in accessing classroom equipment and they were aware of the benefits from integrating their teaching and learning activities including assessment.

\section{The implementation of web-based learning}

Learning through websites means that the participants in the classroom require internet and appropriate websites as the sources of learning in the classroom. According to the findings of the interview, observation, and documentation, the teacers considered that the students have to look for additional sources to be compared that would be beneficial for their learning activities and it would bestow their knowledge into the real-life situation.

The teachers' efforts in integrating web-based sources to the students were successfully make the students be more independent and critical as they have to look for other sources and try to have their own perspectives. These were in coherence with what Wasim et al. (2014) found in their study. According to them, as the teachers introduce the students to integrate web-based learning in the teaching and learning activities, the students would be encouraged to be more very involved in the activities and it would lead them to learning which are centered to the students.

In the factual implementation, all of the English teachers at that school involved all their students to enrich the knowledge of the students about the real-based mateials that they delivered both in speaking and writing skill. The teachers asked the students to obtain many resources, discuss all of them in group, and design the materials designed by the students themselves. Then, the teachers would measure whether the sources were appropriate to the material or not.

\section{ICT and authentic assessment are requisite}

The significance of ICT and authentic assessment has been noticed by the curriculum coordinator and three English teachers at SMA LIGM. According to the curriculum coordinator in the interview, the necessity of ICT and authentic assessment in the teaching and learning activities has been regulated and the mandatory of 2013 curriculum was also implemented in the school's curriculum development. She also said that SMA LIGM put 2013 curriculum as its fundamental base of teaching and learning activities. Explicitly, she also mentioned that all of the teachers at SMA LTI Indo Global Mandiri had understood the concept of the authentic assessment.

Three teachers of English at SMA LTI Indo Global Mandiri also acknowledged in the interview that the importance of ICT and authentic assessment in their teaching and learning activities. The statements are also in line with the documentation and observation parts. According to the curriculum development of the school, every member of the school should emphasize on the use of ICT and the involvement of authentic assessment involving learning, motivation, and attitudes in each aspect of the teaching and learning activities. In the observation, the teachers perceived the significance of ICT and authentic assessment. During their classroom activities, the teachers not only engaged the students with ICT but also assessed the students with real-life materials. Therefore, these findings are in agreement with the Minister of Education and Culture Regulation No. 23 (2016) which rules that the teachers or educators, school (satuan pendidikan) and government or private institutions have to organize authentic assessment.

\section{The teachers concerned aspects of productive skills in the authentic assessment}

According to the results of the interview and observation, it was found that the teachers considered aspects of productive skill in the authentic assessment activities. It is summarized into Table 2 below. 
Wardah Zahra, Rita Inderawati, \& Ismail Petrus

The use of ICT in authentic assessment of the students' productive skills

Table 1. Aspects of productive skills concerned by the teachers

\begin{tabular}{|c|c|c|c|}
\hline \multirow{2}{*}{$\begin{array}{l}\text { Productive } \\
\text { Skills }\end{array}$} & \multirow{2}{*}{ Teachers } & \multicolumn{2}{|c|}{ Aspects of Productive skill } \\
\hline & & Results of Interview & Results of Observation \\
\hline \multirow[t]{2}{*}{$\begin{array}{l}\text { Speaking } \\
\text { Skill }\end{array}$} & Teacher 1 & Content & $\begin{array}{l}\text { Pronunciation and vocabulary } \\
\text { use }\end{array}$ \\
\hline & $\begin{array}{l}\text { Teacher } 2 \\
\text { Teacher } 3\end{array}$ & Fluency and pronunciation & $\begin{array}{l}\text { Fluency and pronunciation } \\
\text { Grammar }\end{array}$ \\
\hline \multirow[t]{2}{*}{ Writing Skill } & $\begin{array}{l}\text { Teacher } 1 \\
\text { Teacher } 2\end{array}$ & $\begin{array}{l}\text { Opening, body and closing } \\
\text { She could not mention the aspects }\end{array}$ & $\begin{array}{l}\text { Opening, body and closing } \\
\text { Spelling }\end{array}$ \\
\hline & Teacher 3 & $\begin{array}{l}\text { Grammar, words selection, spelling, } \\
\text { punctuation, and layout }\end{array}$ & $\begin{array}{l}\text { Grammar, punctuation } \\
\text { spelling. }\end{array}$ \\
\hline
\end{tabular}

Table 1 shows that all the teachers stated that they should consider four sub-aspects of speaking as suggested by Nunan (2003) in designing authentic assessment. Besides, teacher 1 in the interview indicated that she was more into the content limitation of the materials which is similar to theory of Gower, Philips, and Walter (1995). They suggest that the teachers should limit what should be assessed in their classrooms. Therefore, it can be concluded that all the teachers involved the appropriate aspects of speaking skill. In writing skill, the results of the interview and observation of teacher 1 and 3 highlighted the aspects as suggested Correspondingly, these aspects were involved in fundamental aspects of writing skill recommended by Harmer (2015). Besides, teacher 2 could not mention the aspects of writing skills in the interview session. It could be the results of unawareness of the teacher about what she needs to fill unless for filing. Although teacher 2 could not remember about the aspects of writing in the interview, she considered certain aspects of writing in taking authentic assessment in her classroom. In the observation, she considered the students' spelling and punctuation while having authentic assessment integrated with ICT and she was frequently measured the students' writing skill through self and peer review.

In a like manner, four lesson plans, rubrics, and the students' works were analyzed. First, lesson plans listed the same aspects of both speaking and writing skills. In speaking skill, all of the teachers of English concerned intonation, pronunciation, fluency, content, and vocabulary as indicators of aspects of speaking skill. Moreover, in terms of writing skill, the teachers put layout, grammar, words selection, structure, and punctuation.

Table 3. Scoring rubrics and Instrument from the lesson plans

\begin{tabular}{llll}
\hline Competency & \multicolumn{1}{c}{ Main Focus } & \multicolumn{1}{c}{ Productive skills } \\
\cline { 3 - 4 } \multicolumn{1}{c}{ Domains } & & Speaking & \multicolumn{1}{c}{ Writing } \\
\hline Affective & The students' growth in emotional field & Observation checklist & \multicolumn{1}{c}{ Observation checklist } \\
Cognitive & Knowledge in the learning process & \multicolumn{1}{c}{$\begin{array}{c}\text { Scoring guideliness } \\
\text { Psychomotor }\end{array}$} & $\begin{array}{l}\text { Physical skills } \\
\text { Intonation, pronunciation, coherence, grammar, } \\
\text { fluency, content and accuracy and content } \\
\text { vocabulary }\end{array}$ \\
\hline
\end{tabular}

\section{ICT simplifies teaching, learning, and assessing activities}

In reference to teachers' interview, all the teachers said that the classroom activities supported by ICT would very sure simplify nowadays pedagogy. Peculiarly, teachers 1.2 and 3 believed that the simplified ICT-integrated materials were properly functioned and accessible as a means of authentic assessment practices. UNESCO (2011) also supports that ICT and internet can improve the effiency and effectiveness of education and they increase the better changes of educational transformation. Correspondingly, the convenience brought by the
ICT is proven by the documentation and observation. The teachers' assessment instruments integrated by the ICT tools became more practical to the students as the teachers could simply deliver the assessment instruments to the students with a few problems and ICT positively affected the students' products. The products implied the sophisticated outcomes of the students. Further, the benefits experienced by the teachers are similar like what Selwyn (2003) has been stated that ICT applied nowadays is currently being used to make the all the activities of teaching and learning activities become more effective and efficient. 
The use of ICT in authentic assessment influences the students' performances

All of English teachers at SMA LIGM in the interview agreed that integrating ICT in authentic assessment would positively motivate the students to strive for valuable performances. According to interview, the teachers stated that could the students provide reliable sources to smarten their performances as a part of authentic assessment in the classroom, the students would get additional scores. During the process of the observation which were in line with the interview sessions, the teachers attempted to positively stimulate the students with ICT integrated into the assessment materials in the classrooms by connecting every aspect of the assessment with their real-life and integrating it with ICT. The teachers carried out specific indicators with the help of some strategies written in their lesson plans to direct the students in getting additional information with curiosity. Also, the students' works showed that the teachers' efforts in stimulating the students with certain assessment activities integrated with ICT influenced the students' works. As the teachers involved the students into activities which required the students' higher order thinking skill through productive skills' assessment integrated with ICT in such a way, it surely influenced the students' performances. Dudeney (2000) states that the use of ICT tools have potency to benefit the students in developing their English skills.

\section{The problems}

\section{Limited time}

Insufficient time becomes one of the major issues in integrating ICT to the materials. UNESCO (2011) agrees that limited time in the classroom would affect the teachers' readiness in their preparation. Sicilia (2005) revealed in her study that most of her participants were struggled by adequate time. In relation to this, two from the English teachers at SMA LIGM expressed in their interview that ICT limited their time. Teachers 2 and 3 in the interview compared that the integration of ICT for either teaching or assessing activities in her classroom took more time and the integration of ICT for the teaching, learning, and assessing activities was shortened their effective time in delivering the materials in the classroom. Specifically, they stated that sets of the ICT preparation in the classroom needed a lot of time. Regardless of the two teachers mentioned above, teacher 1 was certain in her interview that ICT supported her activities in the classroom on the whole without any problems including the lack of time.

Further, the lesson plans depicted that all of the teachers have allocated exact time while having ICT as one of their teaching, learning, and assessing aids. Surprisingly, the observations held to all of the teachers revealed that all of the teachers faced the same problems-lack of time when integrating ICT in their classrooms. All of them indicated that they did not follow the time allocation they arranged in their lesson plans. In addition, during the observation, teacher 1 seemed to be difficult to manage her time when it came to applying ICT in her classroom. Afterward, she frequently exceeded the time allocation regulated by the school. She often took the students' break time to continue her activities with the students in the classrooms.

\section{Network connection}

Based on the observation done, it was found that the issues on the network connection was one of the problems faced by the teachers. Moreover, according to UNESCO (2011), network and connection failure is included to one of possible variables that could be considered in the use of ICT at the classroom. During the observation, all the tree teachers were found that they had troubles in connecting their and the students' devices to internet or network available at the school. Teacher 1 discovered that she could not turn on the available multimedia projector in the classroom. It was assumed that there was any failure in the connection related to the cables or the electric socket. Teacher 2 observed that as she sent the materials through email, some of the students didn't have internet connection. Moreover, teacher 3 also experienced in disconecting to internet network. The website showed by teacher 3 cannot be frequently loaded.

\section{Lack of ICT awareness}

During the interview, teacher 2 admitted that she got inadequate awareness of ICT integration to teaching, learning and assessing materials as she confessed that she was not an innovative teacher. She mentioned that she would prefer choosing traditional methods than developing new ideas in having sophisticated materials in her classroom and she planned to have her resignation soon. Further, she was observed that she was mostly unprepared to the activities which should be integrated into ICT as she stated in her interview session at the first. It is assumed that teacher 2 was not aware of what technology brings to education even though the facilities and infrastructures have surely supported the teachers 
to be aware and have knowledge about ICT. Moreover, teachers who are lack of ICT awareness would negatively impact the students' concept of learning as stated by Thakur (2014) in his study.

\section{The solutions}

Some barriers related to ICT resulting from lack of training activities have been noticed by an expert. According to UNESCO (2011), insufficient training activities is one of major causes of teachers' problems in using ICT. The first solution disclosed by the curriculum coordinator and the teachers in the interview was that the school set up training which was specialized to ICT to all teachers of the school. The training involved the school's IT teachers to be the professional instructor in the training and who are responsible to help other teachers who would face certain problems in using ICT in their classrooms. Through the training, the teachers had an appropriate understanding of ICT. In the observation, it seemed that the teachers purposely managed the students to purposely get involved in the assessment activities that were integrated with ICT.

As all of the teachers of English dealt with a limited amount of time when they integrated assessment materials with ICT, they lengthen their activities in the classrooms into one or two additional meetings and added their duration in each meeting to cover all the activities she arranged in her lesson plan. Certainly, this made some discrepancy between the allocated time in the lesson plans and in the real implementation. However, teacher 2 claimed that it would perhaps negatively influence the students' performances in certain aspects; therefore, she decided to assign the students with tasks that would balance the students' performances with the materials that were skipped.

According to UNESCO (2011), failure in network connection could be included as several barriers dominantly faced by the teachers. Through this theory, teachers using ICT in their classroom activities should pay heed to the available network connection. In relation to this, it is proven that teachers of English at SMA LIGM run into inadequate network connection while having ICT during their assessment activities. According to the findings of the interview and the observation, it was found that the three teachers uttered that they would innovate the drawbacks happened in their classroom while applying assessment integrated by ICT in the classroom. Preferably, the teachers prefered to provide internet connection by themselves rather than letting the students learning without any connection. By covering up the network by themselves, the teachers could incorporate ICT to their assessment and prevent the minor problem in the classroom.

\section{CONCLUSION}

This study conducted to describe the types and the implementation of ICT used on the authentic assessment of the productive skills of the students, the problems faced by the English teachers and the solutions from the teachers in using ICT in the authentic assessment in the productive skills. First of all, it is determined from the results of the study that the teachers made use of three types of ICT which were mobile learning, classroom equipment, and webbased learning creatively based on their specific purposes. Second, most of the teachers had a significant understanding about authentic assessment and they were mostly ICT literate since both authentic assessment and ICT are necessary. With these intentions, the teachers had various methods in implementing the three types of ICT tools based on the types of authentic assessment concerning aspects of productive skills that they were teaching for the purposes of simplifying assessment activities and influencing the students' performances. Third, they went through three main difficulties in using ICT and constructing authentic assessment by the integration of ICT. The last, they were educated and motivated to have their solutions to overcome the difficulties.

\section{REFERENCES}

Badan Akreditasi Nasional. (2018). Laporan standar akreditasi tahun 2018 tingkat sekolah menengah dan madrasah. Retrieved from http://ban-smindonesia.kemendikbud.org/.

American Library Association. (1998). Resource guides for school library media program development. Retrieved 26 November, 2018 from

http://www.ala.org/PrinterTemplate.cfm?Sectio n=Resource_Guides\&Template=/ContentMana gement/ContentDisplay.cfm\&ContentID $=1528$ 8.

Cohen, L., Manion, L., \& Morrison, K. (2011). Research methods in education ( $7^{\text {th }}$ ed). Retrieved from http://cw.routledge.com/textbooks/cohen7e/.

Dudeney, G. (2000). The internet and the language classroom. Cambridge: Cambridge University Press. 
ENGLISH REVIEW: Journal of English Education

Volume 8, Issue 1, December 2019

Fraenkel, J., \& Wallen, N. (2012). How to design and evaluate research in education $\left(8^{\text {th }} \mathrm{Ed}\right)$. New York: McGraw-Hill Inc.

Gower, R., Phillips, D., \& Walters, S. (1995). Teaching practice handbook. Oxford: Macmillan Heinemann.

Harmer, J. (2015). The practice of English language teaching $\left(5^{\text {th }}\right.$ ed.). London: Pearson Education Limited.

Indonesian Ministry of Education and Culture. (2016). Peraturan Menteri Pendidikan dan Kebudayaan No. 22 tentang standar proses. Jakarta: Indonesia The Ministry of Education and Culture.

Indonesian Ministry of Education and Culture. (2017). Peraturan Menteri Pendidikan dan Kebudayaan No. 27 tentang standar kompetensi kelulusan. Jakarta: Indonesia The Ministry of Education and Culture.

International Communication Union. (2017). Global ICT development index. Retrieved from https://www.Itu.int/net4/ITUD/idi/2017index.ht $\mathrm{ml}$.

Jonassen, D., Howland, J., Marra, R. M., \& Crismond, D. (2009). Meaningful learning with technology. New Jersey: Pearson Education Inc.

Luo, H., \& Lei, J. (2012). Educational stages and interactive learning: From kindergarten to workplace training. China: Peking University Press. Retrieved from 10.4018/978-1-4666-01376.ch005.

Miles, M. B., \& Huberman, M. (1994). Qualitative data analysis: A sourcebook of new methods. London: Sage Publication, Inc.

Mueller, J. (2014). What is authentic assessment? Retrieved November 28, 2018 from http://jfmueller.faculty.noctrl.edu/toolbox/whatis it.html.

Nunan, D. (2003). Practical English language teaching. Pennsylvania, NY: McGraw-Hill Education.

Ozaslan, E. N., \& Maden, Z. (2013). The use of powerpoint presentation in the department of foreign language education at Middle East technical university. Middle Eastern \& African Journal of Educational Research, 2, 38-45.

Sharples, M., Adams, A., Ferguson, R., Gaved, M., McAndrew, P., Rienties, B., Weller, M., \& Whitelock, D. (2014). Innovating pedagogy 2014: Open University innovation report 3. Milton Keynes: The Open University.
p-ISSN 2301-7554, e-ISSN 2541-3643

https://journal.uniku.ac.id/index.php/ERJEE

Selwyn, N. (2003). ICT in non-formal youth and adult education: defining territory. Philadelphia: OECD/NCAL International Roundtable.

Sicilia, C. (2005). The challenges and benefits to teachers' practices in constructivist learning environments supported by technology. Unpublished master thesis, McGill University, Montreal.

Thakur, N. (2014). A study on awareness of trained teachers in relation to information and communication technology. IOSR Journal of Research \& Method in Education (IOSRJRME), 4(1), 06-11. doi: 10.9790/7388-04150611.

Thanyalak, O. (2012). Developing speaking skills using three communicative (discussion, problemsolving, and role-playing). International Journal of Social Science and Humanity, 2(6). doi: 10.7763/ijssh.2012.v2.164.

Trisanti, N. (2014). English teacher's perspective on authentic assessment implementation of curriculum 2013. 61 ${ }^{\text {st }}$ TEFLIN International Conference, Solo, Indonesia: Semarang State University.

UNESCO. (2011). UNESCO ICT: Competency framework for teachers. Fontenoy, Paris: United Nations Educational, Scientific and Cultural Organization.

Wasim, J., Sharma, S., Khan, I., \& Siddiqui, J. (2014). Web based learning. International Journal of Computer Science and Information Technologies, 5(1), 446-449.

Zhang, W., \& Han, C. (2012). A case study of the application of a blended learning approach to web-based college English teaching platform in a medical university in eastern China. Theory and Practice in Language Studies, 2, 1961-1970. doi: 10.4304/tpls.2.9.1961-1970.

Zaim, M. (2013). Asesmen otentik: Implementasi dan permasalahannya dalam pembelajaran bahasa Inggris di sekolah menengah. Proceeding of the International Seminar on Languages and Arts. Padang: State University of Padang. 
Wardah Zahra, Rita Inderawati, \& Ismail Petrus

The use of ICT in authentic assessment of the students' productive skills 